\title{
IMPLEMENTASI METODE SARISWARA KI HADJAR DEWANTARA DALAM MEMBANGUN KEMERDEKAAN JIWA INDIVIDU ANAK
}

\author{
Helmi Denada Ari Shandy, Novi Trilisiana \\ Kurikulum dan Teknologi Pendidikan, FIP, UNY \\ e-mail: helmi.denada2015@student.uny.ac.id,novitri@uny.ac.id
}

\begin{abstract}
Abstrak
Penelitian ini bertujuan untuk 1) Mendeskripsikan metode pendidikan Metode Sariswara di Club Sariswara Yogyakarta, 2) Mendeskripsikan penerapan Metode Sariswara Yogyakarta, dan 3) Mendeskripsikan faktor pendukung dan penghambat dalam penerapan metode sariswara di Club Sariswara Yogyakarta. Penelitian ini menggunakan pendekatan studi kasus dengan metode kualitatif. Subyek penelitian ini yaitu Direktur Laboratorium Sariswara, Pamong, orang tua dan peserta didik. Objek penelitian ini mengenai penerapan Metode Sariswara di Club Sariswara Yogyakarta. Pengumpulan data dilakukan melalui observasi, wawancara dan studi dokumen. Analisis data menggunakan model Miles dan Huberman, yaitu reduksi, penyajian data dan kesimpulan. Uji validitas data melalui triangulasi sumber dan teknik. Hasil penelitian menunjukkan bahwa: (1) Metode sariswara merupakan metode mendidik anak dengan menggabungkan 3 pelajaran sekaligus yakni lagu, sastra dan cerita. Penggabungkan ini menjadikan pendidikan tidak hanya berfokus pada aspek kognitif melainkan juga melibatkan aspek afektif serta psikomotor secara bersamaan. (2) Penerapan metode sariswara dilakukan menggunakan lagu permainan anak (tembang dolanan anak). Dalam penerapan Metode Sariswara terkandung pembelajaran tentang Kemerdekaan Jiwa Individu, yakni: a) Keselarasan. b) Kekeluargaan. c) Musyawarah. d) Toleransi. e) Kebersamaan. f) Demokrasi. g) Disiplin. h) Tanggungjawab. (3) Faktor Pendukung dalam implementasi Metode Sariswara: a) Pembelajaran yang menyenangkan. b) Pesan yang mudah diterima anak. c) Pamong yang penuh kasih sayang. Faktor Penghambat, a) Terbatasnya jumlah Sumber Daya Manusia. b) Peserta didik yang mengalami beberapa kesulitan dalam mencintai budaya khususnya dalam bahasa Jawa. c) Lembaga yang kurang mendukung terhadap gerakan Metode Sariswara, baik lembaga Tamansiswa ataupun lembaga pemerintah.
\end{abstract}

Kata kunci: konsep pendidikan Ki Hadjar Dewantara, metode Sariswara, kemerdekaan jiwa Individu

\section{THE IMPLEMENTATION OF SARISWARA KI HADJAR DEWANTARA METHOD IN DEVELOPING CHILDREN INDEPENDENT SPIRIT}

\begin{abstract}
This research aims to 1) Describe the educational methods of the Sariswara Method at the Sariswara Club Yogyakarta, 2) Describe the implementation of the Sariswara Method at Sariswara Club Yogyakarta, and 3) Describe internal and external obstacles to implement the Sariswara Method at Sariswara Club Yogyakarta. This research uses a case study approach with a qualitative method. The subject of this research is the Director of The Yogyakarta Sariswara Laboratory, teacher, students, and parents. The object of this research is the implementation of the Sariswara method at the Sariswara Club Yogyakarta. Data are collected through observation, interview and study of document. Data analysis used employing Miles and Huberman models, namely reduction, data presentation and conclusion. Test the validity of the data is done through triangulation of sources and techniques. The result of this research shows that: (1) The Sariswara Method is a method of educating children by combining 3 lessons at once, namely songs, literature and stories. This integration makes education not only focus on cognitive aspects, but also involves affective and psychomotor aspects simultaneously. (2) The application of the Sariswara Method is carried out using children's play songs (children's song). In the application of the Sariswara Method contained learning about Individual Soul Independence, namely: a) Harmony. b) Family. c) Deliberation. d) Tolerance. e) Togetherness. f) Democracy. g) Discipline. h) Responsibility. (3) Supporting Factors in the application of the theater method: a) Enjoyable learning. b) Messages that are easily received by children. c) A loving guardian. Inhibiting Factors, a) Limited number of Human Resources. b) Students who have difficulty in learning special culture in Javanese. c) Institutions that are less supportive of the Sariswara Method movement, both Tamansiswa Institutions and government agencies.
\end{abstract}

Keywords: Ki Hadjar education concept, Sariswara method, individual soul independence 


\section{PENDAHULUAN}

Di zaman modern seperti sekarang pendidikan merupakan hal yang tidak bisa dianggap remeh bagi berlangsungnya kehidupan. Hal ini berkaitan dengan pendidikan sebagai upaya membentuk karakter manusia menjadi lebih baik. Wilujeng (2017:4) menjelaskan bahwa pendidikan, khususnya pendidikan karakter membantu pembentukan karakter secara berkesinambungan dan mengembangkan individu agar menjadi pribadi yang lebih baik. Dewasa ini tidak sedikit kita jumpai peristiwa atau tindakan yang memprihatinkan di Indonesia. Mulai dari konflik antar golongan, ras, lawan politik, sikap intoleran, kekerasan, penganiayaan dan berbagai perilaku tak elok lainnya. Realita demikian menjadi masalah sosial yang sampai saat ini masih menjadi tanggung jawab kita bersama untuk dipecahkan. Salah satu kekerasan yang ada terjadi di lingkungan sekolah. Diberitkan oleh Tempo (2019) bahwa KPAI merilis jumlah kekerasan di dunia pendidikan sebanyak 127 kasus selama periode Januari hingga Oktober 2019. Data tersebut menunjukkan bahwa krisis moral yang melanda bangsa kita telah mencapai tahap memprihatinkan.

Sudah banyak contoh kasus dari kekerasan yang terjadi di lingkungan pendidikan, seperti kekerasan, bullying, persekusi dan lain sebagainya. Kekerasan tak hanya soal guru kepada siswa, atau siswa kepada siswa lainya, bahkan lebih parah kekerasan terjadi oleh siswa terhaap gurunya sendiri. Seperti yang terjadi belum lama ini di Kendal, Jawa Tengah. Terjadi penganiayaan siswa di SMK NU 3 Kaliwungu terhadap gurunya hanya karena sang guru menanyakan siswanya yang tidak membawa alat peraga. (Putranto, 2018). Kasus lain yakni penganiayaan siswa terhadap guru hingga menewaskan sang guru di sebuah sekolah di Sampang, Jawa Timur. (Sohuturon, 2018). Beberapa kasus tersebut menguatkan bahwa pendidikan karakter/moral perlu di garap secara lebih serius.

Metode pendidikan untuk membangun budi pekerti, moral atau akhlak sebenarnya sudah lama digagas dan dilaksanakan oleh para pendiri bangsa Indonesia. Dalam hal ini ialah Ki Hadjar Dewantara, seorang putra pangeran yang memilih menanggalkan gelar bangsawannya demi bergaul serta mengabdi kepada rakyat dan kemanusiaan. Ki Hadjar yang dikenal sebagai Bapak Pendidikan Nasional melihat pendidikan mampu mengubah watak dan sikap bangsa untuk menjadi bangsa yang mempunyai derajat yang tinggi dan sejajar dengan bangsa lain (Gunawan, 2012). Artinya Ki Hadjar sudah memandang pentingnya keluhuran budi sejak lama bagi bangsa Indonesia. Pemikiran visioner seperti inilah yang menjadikan beliau layak untuk diangkat dalam hal-hal berkaitan dengan pendidikan.

Dalam upaya membangun budi pekerti luhur, dari banyak gagasan dan metode oleh $\mathrm{Ki}$ Hadjar Dewantara, beliau memiliki metode yang disebut dengan Metode Sariswara. Metode Sariswara merupakan ramuan yang tergabung atas kombinasi gagasan dari berbagai penjuru dunia oleh Ki Hadjar Dewantara. Dilansir dari harian Kedaulatan Rakyat mengenai metode sariswara :

Ki Hadjar Dewantara mengembangkan pendidikan nasional berbasis budaya lokal sendiri dengan proses akulturasi sistem dari seluruh dunia secara harmonis. Ki Hadjar mengadopsi seni permainan (Friedrich Frobel, Jerman), panca indera \& kemerdekaan (M. Montessori, Itali), wirama (R. Steiner, Kroasia-Austria), seni musik dan tari (J. Dalcroze, Austria-Swiss) dan seni \& alam lingkungan (R. Tagore, India). Metode Sariswara sebagai pendidikan yang menyenangkan (Agus, 2019).

Pada bulan Desember 2018, peneliti melakukan wawancara dengan $\mathrm{Ki}$ Priyo Dwiarso yang merupakan Anggota Majelis Luhur Tamansiswa dalam sebuah forum sarasehan yang diadakan di Pendopo Tamansiswa Yogyakarta, beliau menjelaskan bahwa praktik pendidikan yang umum diadakan di sekolah-sekolah hari ini yang terasa sangat berbeda dengan praktik pendidikan di gagas $\mathrm{Ki}$ Hadjar Dewantara. Menurut Beliau 
Kebanyakan praktik pendidikan karakter hanya sebatas pada kelas, tatap muka, serta hafalan. Dalam praktiknya tidak menggunakan caracara kreatif yang memadukan wiraga, wirama, wirasa (psikomotor, kognitif, afektif) seperti yang dicontoh oleh Ki Hadjar Dewantara. (Wawancara dengen Ki Priyo Dwiarso, 2018)

Berdasarkan hal yang telah dijabarkan tersebut terkait dengan pendidikan budi pekerti, Metode Sariswara yang dicetuskan oleh $\mathrm{Ki}$ Hadjar Dewantara maka penulis menjadikan hal-hal yang telah disebutkan menjadi fokus penelitian. Praktik pendidikan Budi Pekerti menggunakan Metode Sariswara di Club Sariswara Yogyakarta. Metode Sariswara siswa di Club Sariswara Yogyakarta tersebut memiliki jiwa yang hidup dan ceria sehingga menarik untuk diteliti lebih mendalam.

Harapan kedepannya, penulis dapat menemukan aktualisasi dari Metode Sariswara di sekolah-sekolah maupun lembaga belajar di masa mendatang. Sehingga Metode Sariswara Ki Hadjar ini dapat menjadi senjata dalam membangun kepribadian serta jiwa merdeka bagi para siswa di Indonesia.

\section{METODE PENELITIAN}

\section{Jenis Penelitian}

Penelitian ini menggunakan pendekatan studi kasus dengan metode penelitian kualitatif deskriptif.

\section{Waktu dan Tempat Penelitian}

Penelitian ini berlangsung dari AprilSeptember 2019. Tempat dilaksanakannya penelitian ini yaitu di Club Sariswara Yogyakarta, Jalan Taman Sisswa, No. 31, Wirogunan, Mergangsan, Kota Yogyakarta, Daerah Istimewa Yogyakarta.

\section{Target/Subjek Penelitian}

Target/subjek penelitian ini terdiri dari pamong/guru Club Sariswara, orang tua dan siswa anggota Club Sariswara.

\section{Prosedur}

Prosedur dalam penelitian ini yakni dengan cara mengecek data yang telah diperoleh dari berbagai sumber. Data tersebut dideskripsikan, lalu dikategorikan berdasarkan kesamaan, perbedaan dan yang spesifik dari suber. Dan selanjutnya data yang telah di analisis akan menghasilkan kesimpulan.

\section{Teknik Pengumpulan Data dan Instrumen Pengumpulan Data}

Teknik Pengumpulan data dalam penelitian ini menggunakan wawancara, observasi dan studi dokumentasi.

\section{Teknik Analisis Data}

Dalam penelitian ini peneliti menggunakan metode penelitian deskriptifanalitis, yaitu sebuah metode yang bertujuan untuk memecahkan permasalahan yang ada, dengan menggunakan teknik deskriptif, yakni penelitian, analisis dan klasifikasi (Surahmad, 1982:139) Teknik Pengolahan data peneliti yaitu analisis dan mengatur secara sistematis bahan hasil wawancara dan observasi, menafsirkanya dan menghasilkan suatu pemikiran, pendapat teori atau gagasan yang baru (Raco, 2010:121).

Miles dan Huberman (1984) (Sugiyono, 2015:337) menerangkan bahwa aktivitas dalam analisis data kualitatif dilakukan secara interaktif dan berlangsung terus-menerus sampai tuntas, sehingga datanya jenuh. Data jenuh adalah keadaan dimana data yang telah diperoleh dari berbagai sumber dan teknik hasilnya tetap sama. Analisis data dalam penelitian ini yakni model Miles dan Huberman. Aktivitas yang dilakukan dalam analisis data disini antara lain reduksi data, penyajian data dan kesimpulan.

\section{A. Data Reduction (Reduksi Data)}

Mereduksi data berarti menerangkan, memilih hal-hal pokok, memfokuskan pada hal-hal yang penting, mencari tema dan membuang yang tidak perlu. Dengan demikian data yang telah direduksi akan memberikan gambaran yang jelas dan mempermudah peneliti mengumpulkan data selanjutnya serta mencari data bila diperlukan

B. Data Display (Penyajian Data)

Penyajian data bisa dilakukan dalam bentuk uraian singkat, bagan, 
hubungan antar kategori, flowchart dan sejenisnya. Penyajian data dalam penelitian ini adalah dengan teks yang bersifat naratif.

\section{Conclusion Drawing/Verification}

Penarikan kesimpulan dan verifikasi, kesimpulan awal yang dikemukakan masih bersifat sementara, dan akan berubah bila tidak ditemukan bukti-bukti yang kuat untuk mendukung pada tahap pengumpulan data berikutnya.

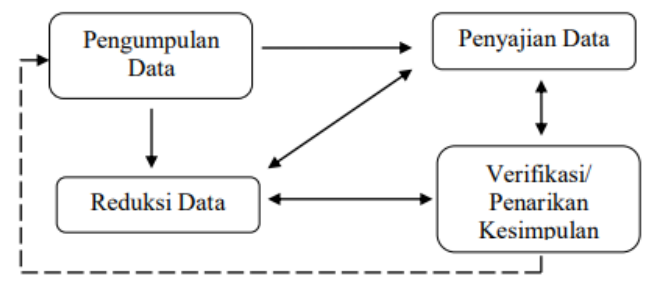

Gambar 1. Teknik Analisis Data

\section{HASIL PENELITIAN DAN PEMBAHASAN}

Hasil penelitian menyajikan informasi mengenai Metode Sariswara, yakni apa yang dimaksud Metode Sariswara di Club Sariswara Yogyakarta, Bagaiamana implementasi metode tersebut serta apa kendala dan pendukung implementasi metode tersebut.

\section{a. Metode Sariswara}

Metode sariswara adalah metode yang menggabungkan pelajaran-pelajaran lagu, sastra dan cerita, seperti yang terdapat di dalam tradisi kebangsaan kita juga. Orang yang mempelajari nyanyian-nyanyian "Macapat" misalnya, dengan sendiri mendapat latihan sastra dan dengan sendiri ia memperoleh pengetahuan tentang berbagai cerita yang terkandung di dalamnya. Dalam gabungan tiga macam pelajaran ini, tergabunglah pula pendidikan rasa, fikiran dan budi pekerti (Dewantara, 1962:277).

Metode Sariswara memiliki landasan pendidikan khas Tamansiswa, Sebagaimana di jelaskan oleh (Rahardjo, 2015) bahwasanya tujuan pendidikan Tamansiswa adalah membangun anak didik menjadi manusia beriman dan bertaqwa kepada Tuhan Yang Maha Esa, merdeka lahir batin, luhur akal budinya, cerdas dan berketerampilan, serta sehat jasmani dan rohaninya untuk menjadi anggota masyarakat yang mandiri dan bertanggung jawab atas kesejahteraan bangsa, tanah air, serta manusia pada umumnya.

Lebih lanjut pembahasan Ki Hadjar Dewantara (1982) mengenai pendekatan dengan cerita, sastra dan lagu ini amatlah perlu, dimana anak-anak menampilkan pertunjukan dengan senang dan gembira. Dengan ini anak dapat secara tidak langsung menangkap pokok isi ceritanya. Secara tidak sadar mereka terinternalisasi berbagai pelajaran kesusilaan, sekalipun baru kelak kemudian hari mereka baru menginsyafinya.

\section{Kesenian dalam Metode Sarisawara}

Kesenian atau keindahan tidak bisa dilepaskan dari Metode Sariswara dalam membentuk kepribadian anak. Kegiatan yang dilakukan di Club Sariswara jika dilihat sekilas memang layaknya sanggar kesenian. Akan tetapi jika diperdalam, akan ditemukan perbedaan dan esensi yang lebih tinggi dari sekadar sanggar seni pada umumnya. Dalam praktiknya memang Metode Sariswara sangat menekankan pada wiraga (gerak raga), wirasa (olah rasa) dan wirama (gerak lagu). Melalui kesenian akan tertanam benih watak atau budi pekerti yang harmonis di daam jiwa anak. Sebagaimana dijelaskan oleh Ki Hadjar Dewantara (1962:328) Kalau kita mengutamakan kesenian nasional dalam Taman Siswa, maka disitulah yang dimaksudkan ialah agar kita dapat menanam benih atau bekal budi pekerti (watak atau tabiat) yang dengan pelajaran kesenian itu kita dapat memasakkan jiwa dan raga anak-anak, hingga kelak mencapai derajat manusia utama serta dapat menyusun perikehidupan yang pantas dalam masyarakat yang akan dipikul bersama-sama oleh mereka sekalian. Tak boleh dilupakan pula, bahwa pelajaran kesenian itu amat besar faedahnya untuk menolak pengaruh "Intelektualisme" yang merajalela hingga mengalahkan moral atau rasa kesucian. 
Dewantara (1962:335) menambahkan bahwa sifat keindahan melelui seni itu sebenarnya tidak lain adalah sifat ketertiban yang menyenangkan rasa kita, maka pendidikan yang bersyarat kesenian itu tidak lebih dan tidak kurang adalah mendidik rasa-ketertiban. Jadi, pendidikan estetis itu dengan sendiri lalu menjadi dasar pendidikan etis atau moral.

\section{b. Implementasi Metode Sariswara}

Penerapan dalam permainan Sapuran.

Dalam permainan anak sering digunakan perumpamaan atau gambaran imajinatif yang bertujuan meningkatkan daya kreatif dan inovatif anak. Demikian pula pada permainan Sepuran. Sepur atau kereta api diperagakan melalui gerak tari menyerupai rangkaian gerbong dengan lokomotifnya. Anak berbaris berurutan, tangan kiri ditopangkan pada bahu kiri teman di depannya, tangan kanan digerakkan ke depan-belakang menirukan gerak pedal dan keberadaan cerobong asap pada kereta, kaki melangkah maju-mundur, lalu berjalan perlahan, semakin cepat dan semakin kencang mengikuti irama tembang. Seperti rangkaian gerbong kereta api, gerbong antar anak tidak boleh terpisah satu dengan lainnya sehingga masing-masing anak berusaha menjaga langkah geraknya. Sementara itu, anak yang berperan sebagai lokomotif harus tanggap terhadap kondisi gerbongnya. Ia harus mampu manjaga keutuhan gerbong dengan cara menata kecepatan dan mencari jalan agar tidak bertabrakan dengan rangkaian kereta dari grup lainnya. Dengan demikian, tembangdan gerak tari sepuran menstimulus enam aspek seperti paparan pada Tabel 1 .
Tabel 1. Aspek-aspek dalam praktik Metode Sariswara lagu Sepuran

\begin{tabular}{|c|c|c|}
\hline \multicolumn{3}{|c|}{ Teks: } \\
\hline \multicolumn{3}{|c|}{$\begin{array}{l}\text { Kok kok kok, jes jes jes... Kok kok kok, jes jes } \\
\text { jes }\end{array}$} \\
\hline \multicolumn{3}{|c|}{$\begin{array}{l}\text { Sepur lengsir maju mundhur, sepur langsir } \\
\text { maju mundhur }\end{array}$} \\
\hline \multicolumn{3}{|c|}{$\begin{array}{l}\text { Tret tret tret, tret Jenggleng... Tret tret tret, tret } \\
\text { jenggleng }\end{array}$} \\
\hline \multirow{3}{*}{\multicolumn{3}{|c|}{$\begin{array}{l}\text { Jes jes jes jes jes jes kok, Jes jes jes jes jes jes } \\
\text { kok } \\
\text { Jes jes jes jes jes kok }\end{array}$}} \\
\hline & & \\
\hline & & \\
\hline \multirow{2}{*}{$\frac{\text { No. }}{1}$} & & Keterangan \\
\hline & Kognitif & $\begin{array}{l}\text { Berusaha } \text { berpikir } \\
\text { mengungkapkan keselamatan } \\
\text { gerbong agar tidak terlepas } \\
\text { dari gerbong depan dan } \\
\text { belakang. }\end{array}$ \\
\hline 2 & Emosi & $\begin{array}{l}\text { Berusaha tidak panik dan } \\
\text { tidak menyalahkan teman } \\
\text { ketika gerbong terlepas. }\end{array}$ \\
\hline 3 & Sosial & $\begin{array}{l}\text { Bersedia menjalin } \\
\text { kebersamaan dengan tim demi } \\
\text { kekompakan dan keselamatan } \\
\text { kereta. }\end{array}$ \\
\hline 4 & Motorik & $\begin{array}{l}\text { Berusaha menyelaraskan } \\
\text { gerak tubuh sesuai wirama } \\
\text { sehingga mampu diajak } \\
\text { berjalan baik lambat ataupun } \\
\text { berjalan cepat. }\end{array}$ \\
\hline 5 & Bahasa & $\begin{array}{lcr}\text { Mampu melafalkan teks } \\
\text { berbahasa Jawa dan } \\
\text { mengetahui artinya dan } \\
\text { mampu menggunakan tiruan } \\
\text { bunyi (onomatipe) }\end{array}$ \\
\hline 6 & Karakter & $\begin{array}{l}\text { Menanamkan sikap tanggung } \\
\text { jawab dan tenggang rasa. }\end{array}$ \\
\hline
\end{tabular}

Penerapan dalam permainan Jamuran

Dalam lagu dolanan anak Jamuran anak mempraktikkan beberapa kegiatan, menyanyi, gerak, menjaga irama, fokus dan kekompoakan satu sama lain. Lagu ini dapat digunakan sebagai sarana untuk mengembangkan daya ijaminasi anak 
Tabel 2. Aspek-aspek dalam praktik Metode Sariswara lagu Jamuran

\section{Teks:}

Jamuran yo ge gethok, jamur opo yo ge gethok

Jamur gajih mberjijih sak ara-ara

Sira bage jamur apa?

Jamur apa?

Jamur gagak,

Jamur kethek menek,

Jamur Gula setangkep

\begin{tabular}{|c|c|c|}
\hline No. & Aspek & Keterangan \\
\hline 1 & Kognitif & $\begin{array}{l}\text { Berusaha berpikir } \\
\text { mengikuti permintaan } \\
\text { 'jamur'oleh yang jaga. }\end{array}$ \\
\hline 2 & Emosi & $\begin{array}{l}\text { Berusaha tidak panik saat } \\
\text { tidak memperoleh }\end{array}$ \\
\hline & & $\begin{array}{ll}\text { pasangan } & \text { ketika } \\
\text { mempraktikkan } & \text { Jamur } \\
\text { tertentu. } & \end{array}$ \\
\hline 3 & Sosial & $\begin{array}{l}\text { Menjalin kebersamaan } \\
\text { ketika Jamur meminta } \\
\text { membentuk tim dengan } \\
\text { Jumlah tertentu. }\end{array}$ \\
\hline 4 & Motorik & $\begin{array}{l}\text { Berusaha menyelaraskan } \\
\text { gerak tubuh sesuai wirama } \\
\text { sehingga mampu diajak } \\
\text { kerjasama membentuk tim } \\
\text { jamur tertentu. }\end{array}$ \\
\hline 5 & Bahasa & $\begin{array}{l}\text { Mampu melafalkan teks } \\
\text { berbahasa Jawa dan } \\
\text { mengetahui artinya dan } \\
\text { mampu menggunakan } \\
\text { tiruan bunyi (onomatipe) }\end{array}$ \\
\hline 6 & Karakter & $\begin{array}{l}\text { Menanamkan sikap } \\
\text { tanggung jawab dan } \\
\text { tenggang rasa }\end{array}$ \\
\hline
\end{tabular}

Metode Sariswara memiliki fungsi membangun karakter kemerdekaan jiwa individu. Hal tersebut dapat dilihat ketika proses belajar dan latihan berlangsung. Nuansa kekeluargaan sangat kental di antara siswa maupun hubungan siswa terhadap pamong. Karakter kemerdekaan jiwa individu menurut Ki Soeratman dalam
Dewantara (1962) terdapat delapan poin penting:

a. Keselarasan

Keselarasan merupakan serba keseimbangan antara kepentingan individu dan kepentingan masyarakat; keseimbangan antara hidup duniawi dan ukhrowi, antara jasmani dan rohani, dan sebagainya.

b. Kekeluargaan

Kekeluargaan adalah sendi hidup yang berlandaskan pada manunggalnya rasa aku dan kita, yang mengutamakan pengabdian kepada keselamatan dan kebahagiaan hidup bersama

c. Musyawarah

Musyawarah adalah upaya bersama untuk mencari penyelesaian dan pemecahan masalah yang menjadi kepentingan bersama berdasarkan persamaan hak dan kewajiban.

d. Toleransi

Toleransi yang dimaksud adalah tenggangrasa, sikap saling menghormati pendapat dan saling menghargai pendirian masing-masing, dalam usaha mencapai cita-cita bersama.

e. Kebersamaan

Kebersamaan adalah perasaan sama harga, sama nilai, sama hak dan kewajiban bagi sesamanya, non-diskriminatif.

f. Demokrasi

Demokrasi mengandung arti keseimbangan dalam mewujudkan hak asasi kemanusiaan dan kewajiban asasi kemanusiaan

g. Tanggung jawab

Tanggung jawab adalah kesanggupan untuk menanggung segala ketentuan yang telah disepakati bersama yang bertujuan untuk mengatur tertib damainya hidup bersama.

h. Disiplin

Merupakan ketaatan dengan penuh kesadaran terhadap segala ketentuan yang telah disepakati bersama. 


\section{c. Faktor pendukung dan penghambat Implementasi Metode Sariswara}

Dalam implementasi pendidikan karakter dengan Metode Sariswara di Club Sariswara Yogyakarta terdapat hambatan dan juga pendukung. Yang menjadi faktor penghambat antara lain:

1. Sumber Daya Manusia

Dalam penerapan metode sariswara yang menjadi kendala salah satunya adalah sumber daya manusia (SDM). Di dalam Club Sariswara sendiri belum banyak yang memahami metode sariswara. Dari sekian pengurus Club Sariswara baru sebagian dari Paguyuban Putro Wayah Tamansiswa yang serius memahami dan mau belajar. Untuk menyikapi hal ini penggerak dari Paguyuban Putro Wayah Tamansiswa terus melakukan kaderisasi melalui kegiatan-kegiatan seperti workshop, seminar, sarasehan, diskusi rutinan selasa di Musem Dewantara Kirti Griya dan kegiatan-kegiatan lainnya.

2. Pamong

Pamong dalam Club Sariswara merangkap sekaligus menjadi instruktur dalam latihan nembang, menari dan dolanan anak. Sejauh ini hanya ada 2 pamong yang tertulis sebagai pamong di Club Sariswara Yogyakarta. Hal ini cukup menyulitkan jika ada pementasan yang besar ataupun ketika nantinya anggota Club Sariswara Yogyakarta semakin besar. Solusi dari hal tersebut, penggerak komunitas yang lain ikut terjun membantu pamong dalam melatih siswa-siswi di Club Sariswara Yogyakarta.

3. Peserta didik

Meskipun sebagian besar peserta didik di Club Sariswara mampu mengikuti proses dalam penerapan metode sariswara, akan tetapi beberapa masih mengalami kendala. Kendala tersebut antara lain ketika kegiatan olah suara, olah gerak badan ketika dan keberanian peserta didik dalam mengekspresikan dirinya. Siasat yang dilakukan pamong adalah melakukan pendekatan secara personal, kemudian memberikan masukan serta arahan sambil membiasakan peserta didik dalam melakukan kegiatan-kegiatan tersebut.

Adapun faktor-faktor pendukung dalam implementasi Metode Sariswara di Club Sariswara adalah :

1. Suasana gembira dalam proses kegiatan.

2. Pesan-pesan moral yang relatif mudah diterima anak.

3. Pamong merupakan mantan didikan langsung dari Ki Hadjar Dewantara yang penuh kasih sayang dan dedikasi.

\section{PENUTUP}

\section{Simpulan}

1. Metode Sariswara merupakan metode mendidik anak melalui kesenian untuk membiasakan segala keindahan dengan menggabungkan pengalaman semua indra yang ada, baik melalui pendengaran, penglihatan, gerakan fisik dan juga perasaan (cipta-rasa-karsa).

2. Metode Sariswara sangat menekankan pendidikan dengan melibatkan otak kiri dan kanan secara harmonis. Implementasi metode sariswara dilakukan dengan cara mengajak anak untuk aktif bergerak secara fisik, mengikuti alunan musik dan diikuti dengan kata-kata dalam lagu yang sarat akan makna dan nilai-nilai kepribadian. Metode sariswara diimplementasikan melalui pementasan operet atau langen carita, pelajaran ataupun tembang dolanan (lagu permianan) anak.

3. Dalam implementasi Metode Sariswara terdapat faktor pendukung dan fakor penghambat. Faktor pendukung dalam metode sariswara antara lain suasana gembira dalam kegiatannya, pesan-pesan yang mudah diterima anak, pamong merupakan hasil didikan langsung dari Ki Hadjar Dewantara. Faktor pengambat dalam Metode Sariswara antara lain terbatasnya jumlah pamong, kurangnya dukungan dari lembaga formal ataupun nonformal pendidikan, anggapan bahwa 
ajaran Ki Hadjar sudah tidak relevan dengan tuntutan zaman.

\section{Saran}

Berdasarkan hasil penelitian dan pembahasan, peneliti memberikan saran sebagai berikut:

1. Bagi peneliti

Bagi peneliti yang tertarik melakukan kajian terkait Metode Sariswara, diharapkan dapat memperbaiki kelemahan-kelemahan yang terdapat dalam penelitian ini dan dapat mengembangkan ke sudut pandang keilmuan lainnya. Selain itu peneliti sebaiknya dapat menggali lebih mengenai metode ini kepada saksi hidup yang pernah bersama atau diajar oleh $\mathrm{Ki}$ Hadjar Dewantara.

2. Bagi Club Sariswara Yogyakarta

a. Komunitas sebaiknya melakukan pendokumentasian secara lebih baik mengenai Metode Sariswara, sehingga semakin mudah dikenal khalayak umum.

b. Komunitas sebaiknya membuka jalurjalur komunikasi yang lebih luas dan intens terhadap lembaga pendidikan maupun komunitas penggerak pendidikan yang ada.

c. Komunitas dapat membuat rancangan atau buku panduan yang runtut mengenai metode Sariswara dengan harapan dapat menjadi acuan bagi sekolah atau lembaga pendidikan lain dalam mempraktikkan Metode Sariswara.

3. Bagi Siswa

Sebaiknya siswa lebih mendalami nilai-nilai yang terkandung di Metode Sariswara dan Karakter Kemerdekaan Jiwa Individu, sehingga dapat menjadi bekal dalam mengamalkannya dalam kehidupan sehari-hari.

\section{DAFTAR PUSTAKA}

Agus. P.K. (9/5/2019). Restorasi Pendidikan. Kedaulatan Rakyat, p. 7.
Bunga, H. (30/10/2019). KPAI: Kekerasan di dunia pendidikan mencapai 127 kasus. Retrieved 12 Desember 2019, from: https://nasional.tempo.co/read/1266367/ kpai-kekerasan-di-dunia-pendidikanmencapai-127-kasus/full\&view=ok

Dewantara, K. H. (1962). Buku I: Pendidikan. Yogayakarta: Majelis Luhur Tamansiswa.

Gunawan, H. (2012). Pendidikan karakter Konsep dan Implementasi. Bandung: Alfabeta.

Ki Hadjar Dewantara, K. S. (1982). Buku 60 Tahun Tamansiswa. Yogyakarta: Percetakan Tamansiswa.

Ki Priyo Dwiarso (2018). Pendidikan Karakter Ki Hadjar Dewantara [Recorded by Helmi]. Yogyakarta, DIY, Indonesia.

Putranto, D.A. (11/11/2018). Video Viral Guru Dikeroyok Murid di Kendal, Kepala SMK NU 3 Kaliwungu: Itu Hanya Bercanda. Retrieved from http://jateng.tribunnews.com/2018/11/11 /video-viral-guru-dikroyok-murid-dikendal-kepala-smk-nu-3-kaliwungu-ituhanya-bercanda

Raco, J. (2010). Metode Penelitian Kualitatif : Jenis, Karakter dan Keunggulanya. Jakarta: PT Gramedia Widiasarana Indonesia.

Rahardjo, S. (2015). KI Hadjar Dewantara: Biografi Singkat 1889-1959. Yogyakarta: Garasi.

Sohutoron. (2/2/2018). Kronologi siswa aniaya guru hingga tewas di Sampang. Retrieved from CNN Indonesia: https://www.cnnindonesia.com/nasional/ 20180202124909-12-273381/kronologisiswa-aniaya-guru-hingga-tewas-disampang

Sugiyono. (2015). Metode Penelitian Pendidikan Pendekatan Kuantitatif, Kualitatif dan $R \& D$. Bandung: Alfabeta.

Surahmad, W. (1982). Pengatar Penelitian Ilmiah: Teknik dan Metode. Bandung: Tersito.

Wilujeng, D. S. (2017). Panduan Implementasi Penguatan Pendidikan Karakter. Jakarta: Erlangga. 